\title{
PROFITABILITAS USAHA AYAM PETELUR DI UD. PUNCAK JAYA JOMBANG DALAM UPAYA EFISIENSI KAPASITAS KANDANG
}

\author{
Dyanovita Al Kurnia \\ * Program Studi Peternakan Fakultas Peternakan Universitas Islam Lamongan \\ JI.Veteran No.53.A Lamongan
}

\begin{abstract}
Penelitian profitabilitas usaha ayam petelur di UD. Puncak Jaya Jombang dengan tujuan menganalisis mekanisme produk peternakan ayam petelur, profitabilitas, dan efisiensi secara teknis, harga dan ekonomis. Penelitian dilaksanakan pada bulan April - Mei 2016, menggunakan metode penelitian kualitatif pada mekanisme produk peternakan ayam petelur dan analisis cobb douglas profit function pada profitabilitas dan produksi frontier pada efisiensi teknis, harga dan ekonomis. Pengambilan sampel secara purposive yaitu pengambilan sampel secara sengaja. Data primer digunakan pada analisis mekanisme produk peternakan ayam petelur sedangkan data sekunder digunakan untuk analisis profitabilitas, dan efisiensi usaha. Hasil penelitian menunjukkan bahwa mekanisme produk peternakan ayam petelur di UD. Puncak Jaya dipengaruhi oleh bibit yang digunakan yaitu jenis unggul Isa Brown, penggunaan pakan dimana penggunaan pakan 112gr/ekor/hari untuk semua umur, vaksin 2 bulan sekali yaitu NDIBLS, penggunaan suplemen organic, dan tiga orang tenaga kerja setiap kandang, dengan produksi telur rata - rata $487 \mathrm{~kg}$ per hari. Profitabilitas usaha ternak ayam petelur dihitung selama 18 bulan pemeliharaan dengan kepemilikan 10.000 ekor menghasilkan profit jangka pendek Rp.33.530.000 per bulan. Dimana profit dipengaruhi oleh harga bibit, pakan, vaksin dan obat-obatan dengan pengaruh negative sedangkan harga tenaga kerja berpengaruh positif terhadap profit. Nilai efisiensi teknis adalah 1.72 , efisiensi harga adalah 3.37 dan efisiensi ekonomis adalah 5.83. Nilai keseluruhan efisiensi lebih besar 1 dalam hal ini berarti masih perlu penambahan faktor produksi.
\end{abstract}

KATA KUNCI : Profitabilitas, Efisiensi, Ayam Petelur

\section{PENDAHULUAN}

FAO tahun 2013 menunjukkan bahwa Indonesia menempati peringkat ke-3 sebagai produsen telur ayam ras terbesar di benua Asia pada tahun 2012 (FAO, 2013). Peningkatan harga pakan yang tajam seringkali membuat peternak ayam petelur menutup usahanya karena biaya produksi pakan yang mahal. Biaya pakan adalah biaya produksi yang cukup besar untuk usaha ayam petelur dengan prosentase 70 $75 \%$ (Achoja, 2014). Sektor peternakan ayam petelur menjadi sektor yang terpukul dan produktivitasnya sering kali turun saat harga pakan naik. Berlainan dengan harga pakan yang cenderung naik, harga telur cenderung konstant dua tahun terakhir. menurut Setiawan (2006) perkembangan harga telur ayam dari tahun ketahun terlihat datar, artinya tidak ada lonjakan harga yang signifikan. Menurut Agustin (2014) permintaan ayam ras petelur dipengaruhi oleh harga telur ayam ras petelur namun tidak begitu besar. Menurut Rouf, et al. (2014) efisiensi skala usaha akan dapat diperoleh apabila terjadi penurunan biaya produksi salah satunya adalah biaya pakan. Selain itu Celli (2013) menyatakan bahwa penurunan biaya produksi juga dapat terjadi apabila biaya produksi rata-rata turun akibat peningkatan produksi per unit output (economic of scope). Keberhasilan usaha peternakan ayam dapat dilakukan dengan melakukan manajemen yang baik. Oleh karena harga input pakan menduduki biaya produksi yang sangat besar sedangkan harga telur konstan maka upaya efisiensi pakan harus dilakukan. Sehingga tidak terjadi pemborosan biaya produksi pakan dan tujuan pemberian pakan dapat optimal pada masing-masing kandang. Kenaikan biaya atau harga pakan berpengaruh negative terhadap profit.

Profit maksimal akan bisa diperoleh apabila faktor-faktor produksi lain yang turut berpengaruh selain pakan seperti vaksin dan obat-obatan, penggunaan tenaga kerja, jumlah layer, ukuran kandang diperhatikan dan dimanajemen dengan baik. Ukuran kandang berpengaruh positive terhadap profit hal ini disebabkan karena jumlah ternak yang semakin banyak maka produksi telur juga akan meningkat. Penambahan jumlah ternak yang dipelihara turut pula mewajibkan peternak untuk menyediakan kandang sebagai tempat tinggal. Sehingga ukuran kandang berpengaruh terhadap kemampuannya dalam menampung kapasitas ternak. Di masyarakat sendiri bentuk dan ukuran kandang dengan jumlah ternak yang sama dapat berbeda-beda ukuran luas serta bentuknya. UD. Puncak Jaya memiliki 3 buah kandang dengan ukuran yang berbeda yaitu kandang A $280 \mathrm{~m}^{2}$ yang menampung 2500 ekor, kandang B sama 
dengan kandang A ukuran $280 \mathrm{~m}^{2}$ maupun kapasitas tampungnya yakni 2500 ekor namun kandang $\mathrm{C}$ berbeda ukuran luas kandangnya yaitu $363 \mathrm{~m}^{2}$ dan kapasitas tampungnya 5000 ekor.

Soekartawi, dkk (1991) dalam Dewi (2012) mengatakan bahwa kegiatan usahatani adalah bagaimana mengalokasikan sumberdaya yang ada secara efektif dan efisien dengan tujuan untuk memperoleh profit yang tinggi pada waktu tertentu. Dikatakan efektif apabila produsen dapat mengalokasikan sumberdaya yang mereka miliki dengan sebaik - baiknya, untuk mendapatkan output yang lebih tinggi dan dikatakan efisien apabila pemanfaatan sumberdaya tersebut (input) dapat diminimalisasi untuk menghasilkan output optimal dapat dicapai (output terbaik).

Efisiensi dalam peternakan dibedakan menjadi efisiensi teknis, efisiensi harga, dan efisiensi ekonomis sehingga untuk mendapatkan output yang maksimal, produsen harus menggunakan input yang dimiliki dengan sebaik - baiknya. Kegiatan peternakan ayam petelur dapat meningkatkan profit jika produsen dapat mengelola faktor produksi dengan seefisien mungkin, karena keberhasilan usaha tidak hanya dilihat dari segi tingginya produksi yang dapat dihasilkan, tetapi juga penggunaan faktor produksi

\section{METODE PENELITIAN}

\section{LOKASI DAN WAKTU PENELITIAN}

Tempat penelitian dilakukan di UD. Puncak Jaya dengan kepemilikan ayam petelur sebanyak 10.000 terletak di Dusun Kupang Desa Tebel Kecamatan Bareng Kabupaten Jombang. Pengambilan data dilakukan pada bulan April - Mei 2016. Pemilihan lokasi peternakan sebagai tempat penelitian dilakukan secara purposive sample yaitu penentuan sampel secara sengaja karena : Tempat penelitian merupakan usaha peternakan ayam petelur yang paling besar di Kecamatan Bareng, Memiliki catatan mengenai harga dan jumlah produksi telur, harga dan jumlah bibit, harga dan jumlah pakan, harga serta jumlah vaksin, obat dan kimia yang digunakan serta harga dan jumlah tenaga kerja, UD. Puncak Jaya baru saja menambah populasi ternaknya sebesar 5000 ekor pada 2014.

\section{MATERI PENELITIAN}

Materi dalam penelitian ini adalah UD.Puncak Jaya Jombang dan data yang diambil adalah meliputi data harga dan jumlah telur yang dihasilkan, harga dan jumlah bibit ayam petelur yang digunakan, harga dan jumlah pakan, harga vaksin, obat, kimia (VOK) serta jumlah yang digunakan. Selain itu juga data harga dan jumlah tenaga kerja dalam satu periode. Data diambil selama 18 bulan semenjak ayam siap telur (umur 5 bulan).

\section{METODE PENELITIAN}

Penelitian ini merupakan studi kasus dengan menggunakan metode survei dan dokumentasi dengan tujuan untuk memperoleh keterangan dan fakta-fakta secara deskriptif kualitatif pada mekanisme produk peternakan ayam petelur, dan kuantitatif pada analisis profitabilitas serta efisiensi di UD. Puncak Jaya. Berbagai hal yang dipertimbangkan dalam penelitian ini adalah terbatasnya waktu penelitian, kemungkinan bias data, kemungkinan informasi baru yang sebelumnya tidak diduga sehingga perlu pendekatan lebih lanjut terhadap informasi yang diperoleh.

Dua jenis data yang digunakan dalam penelitian ini yaitu data primer dan data sekunder. Data primer diperoleh dari observasi dan wawancara dengan quisioner terstruktur sementara data sekunder didapat dari arsip perusahaan berupa catatan biaya - biaya yang dikeluarkan untuk produksi baik biaya untuk pembelian bibit, pakan, vaksin obat-obatan dan kimia, serta biaya untuk tenaga kerja, harga kandang, ukuran kandang, harga sewa tanah dan jumlah ayam petelur yang digunakan, selain itu juga data mengenai jumlah produksi dan harga telur. Data sekunder lain didapat dari studi pustaka baik dari media cetak ataupun elektronik yang berkaitan dengan variabel dan objek penelitian.

Penelitian ini merupakan studi kasus dengan menggunakan metode survei dan dokumentasi dengan tujuan untuk memperoleh keterangan dan fakta-fakta secara deskriptif kualitatif pada mekanisme produk peternakan ayam petelur, dan kuantitatif pada analisis profitabilitas serta efisiensi di UD. Puncak Jaya. Berbagai hal yang dipertimbangkan dalam penelitian ini adalah terbatasnya waktu penelitian, kemungkinan bias data, kemungkinan informasi baru yang sebelumnya tidak diduga sehingga perlu pendekatan lebih lanjut terhadap informasi yang diperoleh.

Menurut Gendro (2011) data primer merupakan jenis data yang diperoleh dan digali dari sumber utamanya, baik berupa data kualitatif maupun data kuantitatif. Ada 2 jenis data yang digunakan dalam 
penelitian ini yaitu data primer dan data sekunder. Data primer diperoleh dari observasi dan wawancara dengan quisioner terstruktur sementara data sekunder didapat dari arsip perusahaan berupa catatan biaya - biaya yang dikeluarkan untuk produksi baik biaya untuk pembelian bibit, pakan, vaksin obatobatan dan kimia, serta biaya untuk tenaga kerja, harga kandang, ukuran kandang, harga sewa tanah dan jumlah ayam petelur yang digunakan, selain itu juga data mengenai jumlah produksi dan harga telur. Data sekunder lain didapat dari studi pustaka baik dari media cetak ataupun elektronik yang berkaitan dengan variabel dan objek penelitian.

\section{HASIL PENELITIAN}

\section{MEKANISME PRODUK PETERNAKAN AYAM PETELUR DI UD. PUNCAK JAYA}

Hasil penelitian menunjukkan bahwa mekanisme produk peternakan ayam petelur di UD. Puncak Jaya dipengaruhi oleh bibit yang digunakan yaitu jenis unggul Isa Brown, penggunaan pakan dimana penggunaan pakan 112gr/ekor/hari untuk semua umur, vaksin 2 bulan sekali yaitu NDIBLS, penggunaan suplemen organic, dan tiga orang tenaga kerja setiap kandang, dengan produksi telur rata - rata $487 \mathrm{~kg}$ per hari.

\section{PROFITABILITAS USAHA}

Rumus analisis profit function digunakan untuk mengetahui variabel yang berpengaruh terhadap profitabilitas dan profit jangka pendek yang diperoleh UD. Puncak Jaya. Rumus analisis profit function adalah sebagai berikut (Mohapatara, 2011) dan Sumartono (1987) :

$$
\operatorname{Ln} \pi^{\prime}=\operatorname{Ln} C+\sum_{\mathrm{i}=1}^{\mathrm{n}} \propto_{\mathrm{i}} \operatorname{Ln} \mathrm{W}_{\mathrm{i}}^{\prime}+\sum_{\mathrm{I}=1}^{\mathrm{n}} \beta_{\mathrm{j}} \operatorname{Ln} \mathrm{Z}_{\mathrm{j}}+\sum_{\mathrm{k}=1}^{\mathrm{n}} \delta_{\mathrm{k}} \mathrm{D}_{\mathrm{k}}
$$

\section{Dimana :}

$\Pi^{\prime}=$ profit dengan harga output per unit (UOP)

C = Intersep

$\mathrm{W}_{1}{ }^{\prime} \quad=$ biaya bibit ayam petelur yang telah dinormalkan (Rp/ekor)

$\mathrm{W}_{2}{ }^{\prime} \quad$ = biaya pakan yang telah dinormalkan $(\mathrm{Rp} / \mathrm{kg})$

$\mathrm{W}_{3}{ }^{\prime}=$ = biaya vaksin obat kimia yang telah dinormalkan (Rp/unit)

$\mathrm{W}_{4}{ }^{\prime} \quad=$ biaya tenaga kerja yang telah dinormalkan (Rp)

$Z_{1} \quad=$ biaya penyusutan kandang (Rp/periode)

$\mathrm{Z}_{2} \quad$ = ukuran kandang $\left(\mathrm{m}^{2}\right)$

$D_{k} \quad=$ peubah sandi jumlah ternak tiap kandang,

Dimana :

$\mathrm{D}=1$, adalah 1 kandang kapasitas 5000 ekor

$\mathrm{D}=0$, adalah 2 kandang kapasitas 5000 ekor

$\alpha_{i}, \beta_{j}$ dan $\delta_{k}=$ koefisien regresi yang dicari

Apabila :

a) t hitung $<$ t Tabel $1 / 2 \propto(\mathrm{db}=\mathrm{N}-\mathrm{k}-1): \mathrm{H}_{0}=$ diterima

b) t hitung $\geq 1 / 2 \propto(\mathrm{db}=\mathrm{N}-\mathrm{k}-1): \mathrm{H}_{1}=$ diterima yang berarti variabel bebas yang diuji berpengaruh nyata terhadap variabel terikat yaitu tingkat profitabilitas.

Dimana :

$\mathrm{n}=$ jumlah sampel

$\mathrm{k}=$ banyaknya koefisien regresi

Hasil analisis dapat dilihat pada tabel berikut : 
Tabel 1. Coefficient Regresi Linier Berganda Variabel Yang Mempengaruhi Profitabilitas

\begin{tabular}{lllllll} 
& \multicolumn{2}{l}{$\begin{array}{l}\text { Unstandardized } \\
\text { Coefficients }\end{array}$} & \multicolumn{2}{l}{$\begin{array}{l}\text { Standardized } \\
\text { Coefficients }\end{array}$} & & \\
\cline { 2 - 5 } Model & $\mathrm{B}$ & Std. Error & Beta & T & Sig. \\
\hline (Constant) & 33.53 & 3.390 & & 9.890 & .000 \\
Biaya bibit & -1.095 & .530 & -.367 & -2.068 & .047 \\
Biaya pakan & -1.441 & .477 & -.473 & -3.021 & .005 \\
Biaya vaksin \&obat & -.028 & .079 & -.089 & -.349 & .730 \\
Biaya tenaga kerja & .263 & .253 & .328 & .746 & .461 \\
Dummy & .054 & .031 & .089 & .162 & .872 \\
\hline
\end{tabular}

Profit maksimal jangka pendek yang didapat oleh UD. Puncak Jaya berdasarkan analisis tersebut terlihat dari nilai konstanta yaitu 33.53 juta setiap bulan. Apabila tidak dilakukan pembelian bibit kembali dalam satu periode yang sama dan faktor lain dianggap konstant atau citeris paribus.

Hasil analisis dari Tabel 1 didapatkan model persamaan regresi sebagai berikut :

$\pi=33.53-1.095 \mathrm{X}_{1}-1.441 \mathrm{X}_{2}-0.028 \mathrm{X}_{3}+0.263 \mathrm{X}_{4}+0.054 \mathrm{D}$

berdasarkan model diatas dapat diketahui bahwa fungsi profitabilitas di UD. Puncak Jaya dipengaruhi oleh biaya untuk pembelian bibit, pakan, VOK, serta tenaga kerja. Dimana setiap kenaikan harga bibit sebesar satu satuan akan menurunkan nilai profit sebesar $1.095 \%$. Apabila harga bibit naik $100 \%$ maka profit akan turun sebesar 109,5\% sehingga upaya untuk mengoptimalkan produksi dengan menggunakan bibit unggul perlu dilakukan agar profitabilitas tidak menurun. Menurut majalah inovet (2016) naiknya harga berbagai input produksi ayam petelur seperti misalnya bibit DOC, telah mendorong usaha peternakan untuk berproduksi lebih efisien guna mendapatkan hasil yang optimal. Guna mencegah kerugian dan mengoptimalkan ongkos produksi tak lain adalah produktivitas ternak harus ditingkatkan. Biaya untuk pembelian bibit menduduki $13-14 \%$ biaya produksi usaha ayam petelur.

Usaha ternak unggas intensif umumnya menggunakan jenis-jenis unggul yang telah mengalami seleksi terus menerus seperti broiler, ayam petelur, kalkun dan itik. Berbagai strain unggas telah tersedia di pasaran dunia yang dihasilkan oleh berbagai perusahaan multinasional seperti Aviagen, Hubbard, Lohmann untuk broiler dan Isa, Hyline, Hendrix Poultry untuk petelur. Hampir semua negara di dunia penghasil broiler maupun petelur akan menggunakan salah satu atau lebih dari ayam-ayam yang dihasilkan dari perusahaan tersebut, baik dari parent maupun grand parent, bahkan sampai tingkat great grand parent (Tangendjaja, 2007).

Kenaikan harga pakan sebesar satu satuan akan menurunkan nilai profitabilitas sebesar $1.441 \%$. Sehingga apabila harga pakan naik $100 \%$ maka profit akan turun sebesar $144.1 \%$. Hal ini sesuai dengan penelitian Juwandi (2003) dan Kamillah (2015) yang menyatakan bahwa harga pakan berpengaruh terhadap profitabilitas usaha. Semakin meningkat harga pakan maka profitabilitas juga akan turun dengan signifikan. Hal ini disebabkan pakan menduduki biaya produksi terbesar yakni $70-80 \%$. Komponen penyusun pakan yang banyak berasal dari import menyebabkan biaya pakan tidak bisa diperkirakan oleh peternak. Untuk itu upaya efisiensi pakan perlu dilakukan dengan sangat baik. Penggunaan suplemen seperti yang dilakukan di UD. Puncak Jaya dimaksudkan agar terjadi efisiensi pakan dengan mengoptimalkan fungsi saluran pencernaan sehingga fungsi pakan dapat sesuai dengan tujuan pemberian.

Kenaikan harga vaksin dan obat-obatan sebesar satu-satuan akan menurunkan profitabilitas usaha di UD. Puncak Jaya sebesar $0.028 \%$. Maka apabila harga vaksin dan obat-obatan naik $100 \%$ akan menurunkan profit sebesar $2.8 \%$. Vaksin, obat-obatan, kimia (VOK) digunakan dalam upaya penanganan dan pengendalian penyakit. Suplemen, obat, dan desinfektan merupakan salah satu biaya produksi yang 
rutin dikeluarkan oleh peternakan ayam petelur di UD. Puncak Jaya. Zumrotun (2015) menyatakan bahwa semenjak krisis moneter harga vaksin obat dan kimia buatan pabrik dirasakan peternak cukup mahal. Disisi lain pengurangan dosis atau tanpa pemberian vaksin, obat, dan kimia dalam pemeliharaan ayam petelur akan menimbulkan suatu masalah yang cukup serius yaitu terjadi penurunan kesehatan atau bahkan terjadi peningkatan angka kematian. Hal ini akan mengakibatkan terjadi penurunan produksi sehingga tidak tercapai standart produksi yang diinginkan dan profitabilitas usaha akan turun.

Tamaluddin (2014) menyatakan dalam pemeliharaan ayam petelur, peternak memerlukan obatobatan (antibiotika, anti cacing), dan vaksin. Vaksinasi harus diulang berkala termasuk obat-obatan untuk cacing. Prosentase total biaya produksi untuk pembelian vaksin, obat-obatan serta kimia adalah $2 \%$.

Kenaikan biaya untuk tenaga kerja dapat meningkatkan profitabilitas usaha di UD. Puncak Jaya sebesar $26 \%$ pada saat ditambahkan tenaga kerja $100 \%$. Hal ini dikarenakan nilai yang didapat dari analisis regresi berganda dari Tabel 13 untuk koefisien regresi biaya tenaga kerja adalah bernilai positif sebesar $0.263 \%$. Maka semakin besar biaya yang digunakan untuk pembelian tenaga kerja dapat meningkatkan profit. Hal ini tidak sesuai dengan penelitian Yusdja (1983) dalam Juwandi (2003) yang menyatakan bahwa semakin meningkat jumlah penggunaan tenaga kerja semakin tinggi pula biaya yang dikeluarkan peternak untuk tenaga kerja sehingga akan mengurangi profit. Oleh karena itu pula harga tenaga kerja berpengaruh negative terhadap profit peternak. Biaya untuk tenaga kerja menduduki porsi $4.2 \%$ biaya produksi.

\section{VARIABEL-VARIABEL YANG BERPENGARUH TERHADAP PROFITABILITAS}

Profitabilitas usaha sangat menentukan keberhasilan usaha. Setiap peternak akan menginginkan produksi telur yang maksimal dengan mengetahui faktor produksi apa yang berpengaruh sehingga biaya untuk pembelian faktor produksi tidak sia-sia.

Berdasarkan Tabel 1 dapat diketahui bahwa harga variabel input bernilai negative, seperti pada harga untuk pembelian bibit, pakan, vaksin obat kimia (VOK). Hal ini berarti kenaikan harga bibit, pakan, VOK akan menurunkan nilai profitabilitas di UD. Puncak Jaya. Sementara untuk harga tenaga kerja berpengaruh positif terhadap nilai profitabilitas.

Uji t dilakukan dengan membandingkan antara nilai $t$ yang didapat pada Tabel 1 yaitu Tabel Hasil Coefficient Regresi Linier Berganda Variabel Yang Mempengaruhi Profitabilitas dengan t tabel. Uji ini dilakukan untuk mengetahui pengaruh variabel bebas terhadap variabel terikat secara parsial.

Pembelian bibit berpengaruh negatif terhadap profit di UD. Puncak Jaya. Hal ini disebabkan pada pembelian bibit antara kandang A dan B dengan jumlah ternak masing - masing 2500 ekor sama dengan biaya yang dikeluarkan untuk pembelian bibit di kandang $C$ yang memiliki populasi 5000 ekor. Semakin tinggi jumlah ayam petelur yang dimiliki maka semakin tinggi pula pengorbanan dalam memperoleh bibit. Sehingga biaya untuk bibitpun semakin meningkat, tetapi berdasarkan prinsip economic of scale produksi telur akan meningkat.

Harga beli ayam mempunyai pengaruh negative terhadap profitabilitas. Nilai $t$ hitung sebesar 2.068 dengan $t$ tabel=1/2 $0.05(36-8-1)$ maka, nilai t hitung lebih besar dari pada $t$ tabel $(2.068>2.052)$. Berdasarkan perhitungan tersebut dapat dijelaskan bahwa pembelian ayam berpengaruh signifikan terhadap profit. Disebabkan jumlah ternak yang dipelihara semakin meningkat maka biaya untuk pembelian bibitpun semakin bertambah tetapi jika pembelian bibit diikuti oleh produktivitas ayam yang baik maka profitabilitas meningkat dengan peningkatan produksi.

Tabel 1 memperlihatkan bahwa harga pakan berkorelasi negatif terhadap profit. Artinya kenaikan harga pakan akan menurunkan perolehan profit di UD. Puncak Jaya. Hal ini disebabkan karena biaya pakan menduduki porsi $70-80 \%$ dari biaya produksi. Bahkan menurut (Achoja, 2014) peningkatan harga pakan yang tajam seringkali membuat peternak ayam petelur menutup usahanya karena biaya produksi pakan yang mahal. Biaya pakan adalah biaya produksi yang cukup besar untuk usaha ayam petelur.

Harga beli pakan mempunyai pengaruh negatif terhadap profit dan memperoleh nilai $t$ hitung sebesar 3.021 dengan $t$ tabel=1/2 0.05 (36-8-1), maka nilai t hitung lebih besar dari pada t tabel $(3.021>$ 2.052). Hal ini berarti kenaikan harga pakan akan berpengaruh signifikan terhadap profit di UD. Puncak Jaya. Sehingga upaya pemberian pakan harus dilakukan seefektif dan seefisien mungkin.

Poultryhub (2016) menyebutkan feeding manajemen untuk pullets (ayam siap telur) bertujuan untuk mempertahankan tingkat pertumbuhan yang akan mengarah pada pullet mencapai kematangan seksual pada usia yang diinginkan dengan menghindari obesitas. Untuk itu ternak ayam petelur tidak 
dipersyaratkan diberikan pakan secara adlibitum (bebas tak terbatas) selain akan merugikan peternak karena pemborosan pakan, efek negative juga akan diperoleh ternak akibat obesitas itu sendiri yaitu lemak dimungkinkan berada didaerah oviduct (saluran telur) yang akan menutup jalan keluarnya telur sehingga malah justru akan menurunkan produksi.

Pengaruh yang diberikan oleh harga input variabel vaksin obat dan kimia (VOK) berpengaruh negatif terhadap profit. Dimana nilai t hitung sebesar 0.349 dengan $t$ tabel 2.052 maka t tabel lebih besar dari t hitung. Hal ini menunjukkan bahwa harga yang dikeluarkan tidak berpengaruh signifikan terhadap profit yang dihasilkan di UD. Puncak Jaya. Melihat biaya yang dikeluarkan untuk vaksin, obat-obatan dan kimia (VOK) tidak terlalu besar maka UD. Puncak Jaya diharapkan melakukan jadwal vaksinasi yang tepat. Dimana vaksin untuk vaksin ayam petelur periode layer dilakukan setiap 1 bulan sekali. Hal ini dikarenakan dampak dari vaksinasi yang sangat besar bagi pencegahan penyakit.

Vaksinasi direkomendasikan kepada UD. Puncak Jaya untuk dilakukan sebulan sekali dalam upaya mencegah penyakit yang disebabkan karena virus, seperti penyakit New Castle Disease, Aviant Influenza, Infectious Bronchitis dan masih banyak lainnya penyakit yang disebabkan oleh virus. Penyakit karena virus dapat bersifat fatal bagi profitabilitas usaha. Karena nilai mortalitas ayam yang sangat tinggi apabila ternak terserang penyakit tersebut dan dalam waktu yang sangat singkat mortalitas dapat terjadi hingga ribuan bahkan puluhan ribu ekor ternak.

Hy-lyne redbook (2016) menuliskan bahwa penyakit tertentu terlalu luas atau sulit untuk memberantas dan memerlukan program vaksinasi yang rutin. Secara umum, semua ternak harus divaksinasi penyakit marek, Newcastle, Infectious Bronchitis, Infectious Bursal Disease (IBD, Gumboro), dan Avian Encephalomyelitis (AE). Jadwal vaksinasi yang tepat tergantung pada banyak hal seperti eksposur penyakit yang diharapkan, kekebalan ternak, jenis vaksin yang tersedia, dan cara vaksinasi yang dipilih. Oleh karena itu, tidak ada satu program dapat direkomendasikan untuk semua lokasi dan situasi. Karena setiap situasi dan lokasi dimana ternak berada adalah berbeda.

Penggunaan obat biasanya dilakukan apabila di suatu peternakan terdapat penyakit. Dan apabila tidak terjadi penyakit, maka pemberian obat jarang dilakukan kecuali biaya-biaya yang digunakan untuk membeli antiseptic atau desinfektan untuk kebersihan sanitasi kandang dan peralatan. Selain itu pembelian suplemen untuk ternak sering dilakukan tetapi pemakaiannya dilakukan berulang-ulang dan biaya yang dikeluarkan sangat kecil.

Menurut Rasyaf (1989) dalam Nurcholis (2009) menyatakan bahwa nilai mortalitas di Indonesia pada masa bertelur antara $0.03 \%$ hingga $0.5 \%$ per bulan. Tingkat mortalitas yang wajar ini disebabkan karena sistem pemeliharaan khususnya kebersihan dan kesehatan sudah baik dan memenuhi syarat.

Harga yang dikeluarkan untuk tenaga kerja berpengaruh positif terhadap profit. Hal ini dapat dilihat pada Tabel 1. Hasil uji t didapatkan bahwa t hitung adalah sebesar 0.746 , sedangkan $t$ tabel adalah $1 / 2$. 0.05 (36-8-1) dan nilai t tabel adalah 2.052. $t$ hitung lebih kecil dari t tabel $(0.746<2.052)$ sehingga biaya tenaga kerja berpengaruh tidak signifikan terhadap nilai profitabilitas.

Giyanto (2010) menyatakan bahwa harga tenaga kerja berpengaruh positif terhadap profit. Hal ini sesuai dengan hasil penelitian. Karena tenaga kerja di UD. Puncak Jaya hanya 3 orang untuk 10.000 ekor dan pada 1 kandang untuk 5000 ekor digunakan 1 pekerja sehingga upaya penambahan pekerjaan harian selain pemberian pakan dan minum serta pengambilan telur dengan penambahan upah mampu meningkatkan motivasi pekerja dan berimplikasi pada peningkatan profitabilitas.

Suresti et al (2008) dalam Mustika (2011) menyatakan bahwa tenaga kerja yang digunakan untuk usaha ayam petelur skala 5000 ekor adalah $3-13$ orang. Dengan porsi biaya adalah sebesar $4.2 \%$. Berdasarkan hal tersebut maka jika ditambahkan 1 pekerja saja pada kandang $\mathrm{C}$ masih menguntungkan bagi peternak. Sehingga penambahan tenaga kerja akan dapat lebih memudahkan pengontrolan ternak dan pekerjaan lainnya di kandang $\mathrm{C}$. Oleh karena itu penambahan biaya untuk pembelian tenaga kerja di UD. Puncak Jaya masih memberikan profitabilitas yang bertambah tetapi tidak signifikan berdasarkan uji t.

\section{EFISIENSI TEKNIS}

Tabel 2. Hasil Analisis Model Summary Analisis Regresi Linier Berganda Fungsi Produksi 


\begin{tabular}{|c|c|c|c|c|c|c|c|c|c|}
\hline \multirow[b]{2}{*}{ Model } & \multirow[b]{2}{*}{$\mathrm{R}$} & \multirow[b]{2}{*}{\begin{tabular}{|c|c|}
$\mathrm{R}$ & \\
Square
\end{tabular}} & \multirow[b]{2}{*}{$\begin{array}{c}\text { Adjusted } \\
\mathrm{R} \\
\text { Square }\end{array}$} & \multirow[b]{2}{*}{$\begin{array}{c}\text { Std. Error } \\
\text { of the } \\
\text { Estimate }\end{array}$} & \multicolumn{5}{|c|}{ Change Statistics } \\
\hline & & & & & \begin{tabular}{c|} 
R \\
Square \\
Change
\end{tabular} & $\begin{array}{c}\mathrm{F} \\
\text { Change }\end{array}$ & df1 & $\mathrm{df} 2$ & $\begin{array}{c}\text { Sig. F } \\
\text { Change }\end{array}$ \\
\hline 1 & $.720^{\mathrm{a}}$ & .561 & .560 & .7184 & .561 & 6.605 & 2 & 15 & .234 \\
\hline
\end{tabular}

Berdasarkan Tabel 2 dapat diketahui bahwa koefisien determinasi $\left(R^{2}\right)$ sebesar $56 \%$ artinya produksi dapat dijelaskan oleh faktor-faktor produksi sebagai variabel bebas. Sedangkan sisanya dipengaruhi oleh faktor lain diluar model. Berdasarkan Tabel 2 didapat $F$ hitung adalah 6.60 pada taraf $\propto$ 0.05 lebih besar dari F Tabel yaitu 3.68. Sehingga faktor-faktor produksi antara lain tenaga kerja dan VOK (vaksin, obat, kimia) berpengaruh secara bersama-sama terhadap produksi. Berdasarkan Tabel 3 faktor produksi pakan dan bibit tidak dapat dianalisis karena dinggap konstant nilainya.

Tabel 3. Hasil Koefisien Regresi Linier Berganda Fungsi Produksi

\begin{tabular}{|c|c|c|c|c|c|c|}
\hline \multirow{2}{*}{\multicolumn{2}{|c|}{ Model }} & \multicolumn{2}{|c|}{$\begin{array}{l}\text { Unstandardized } \\
\text { Coefficients }\end{array}$} & \multirow{2}{*}{$\begin{array}{l}\text { Standardized } \\
\text { Coefficients } \\
\text { Beta }\end{array}$} & \multirow[b]{2}{*}{$\mathrm{t}$} & \multirow[b]{2}{*}{ Sig. } \\
\hline & & $B$ & Std. Error & & & \\
\hline \multirow[t]{3}{*}{1} & (Constant) & 17.927 & .103 & & 174.27 & .000 \\
\hline & VOK & .053 & .030 & .445 & 1.789 & .094 \\
\hline & Tk & .079 & .113 & .174 & .700 & .495 \\
\hline
\end{tabular}

Tabel 3 memberikan gambaran model regresi fungsi produksi adalah $Y=17.927+0.053 X_{3}+$ $0.079 X_{4}$. Dan apabila diantilog persamaannya menjadi $Y=8.45 X_{3}{ }^{0.053} X_{4}{ }^{0.079}$. Nilai koefisien regresi menunjukkan elastisitas produksi dan dapat diartikan sebagai berikut :

1. t hitung untuk VOK adalah 0.053 lebih kecil dari t tabel yaitu $1 / 20.05(18-4-1)=2.160$. Artinya tidak terdapat pengaruh yang signifikan. Hal ini berarti apabila ada penambahan faktor produksi VOK akan berpengaruh positif terhadap produksi tetapi tidak begitu besar.

2. $t$ hitung untuk tenaga kerja adalah 0.079 lebih kecil dari t tabel yaitu $1 / 20.05(18-4-1)=2.160$. Artinya tidak terdapat pengaruh yang signifikan. Hal ini berarti apabila ada penambahan faktor produksi tenaga kerja satu satuan akan berpengaruh terhadap produksi tetapi tidak begitu besar.

Fungsi produksi selalu bertanda positif sedangkan untuk fungsi profitabilitas bertanda negative hal ini karena fungsi produksi berkaitan dengan output yang diharapkan bertambah dengan penambahan faktor produksi (variabel bebas) sementara untuk fungsi profitabilitas, variabel bebas yang digunakan adalah variabel harga sehingga apabila harga naik maka tentu saja profit menurun.

Nilai konstanta sebesar 8.45 pada persamaan regresi menunjukkan nilai produksi yang didapat. Sehingga apabila dirasiokan dengan nilai produksi riil rata-rata adalah 14.6 ton/bulan maka efisiensi teknis didapat rata-rata adalah 1.72. Nilai ET > 1 sehingga belum efisien tetapi mendekati efisien oleh karena itu maka penambahan faktor produksi seperti Vaksin, obat ataupun kimia (VOK) maupun tenaga kerja masih perlu dilakukan.

Menurut Soekartawi (1987) dalam Ramadhani (2012) bahwa efisiensi teknis dapat ditempuh dengan membeli faktor produksi pada harga murah dan menjual hasil pada harga relatif tinggi. Bila peternak mampu meningkatkan produksinya dengan harga sarana produksi dapat ditekan tetapi harga jual tinggi, maka peternak tersebut melakukan efisiensi teknis dan efisiensi harga atau melakukan efisiensi ekonomi.

\section{EFISIENSI HARGA}

Nilai efisiensi harga didapat dengan cara merasiokan antara NPM (Nilai Produk Marginal) terhadap HFP (Harga Faktor Produksi Rata-Rata) dan didapatkan nilai pada EH adalah $3.37 \%$. Sehingga belum efisien oleh karena itu maka penambahan faktor produksi perlu dilakukan. 
Nilai efisiensi harga (EH) bibit adalah $7.65 \%$ juga $>1$ artinya adalah masih diperlukan penambahan pembelian bibit agar tercapai efisiensi. Semakin besar jumlah bibit ayam petelur yang dipelihara maka diharapkan produksi juga meningkat.

Nilai efisiensi harga $(\mathrm{EH})$ pakan adalah $8.81 \%$ yang sangat jauh dari nilai 1 hal ini berarti pakan yang selama ini diberikan kepada ayam petelur di UD. Puncak Jaya belum efisien walaupun jumlah yang diberikan sangat melebihi yang dipersyaratkan sehingga biaya produksi pakan tidak dapat dihemat karena pemborosan dan tidak berdampak pada produksi. Sehingga tidak tercapai efisiensi harga. Efisiensi harga adalah terjadi apabila dengan biaya seminimal mungkin didapatkan produksi yang optimal.

Menurut Santosa (1995) dalam Novita (2011) jika pemberian pakan dilakukan secara ad libitum atau melebihi kebutuhan akan menjadi tidak efisien walaupun diberikan dalam jumlah banyak karena dapat menyebabkan bahan pakan banyak terbuang dan pakan yang tersisa menjadi busuk sehingga dapat membahayakan ternak apabila termakan. Oleh karena itu upaya pemberian faktor produksi pakan perlu disesuaikan dengan umur ternaknya.

Nilai efisiensi harga VOK adalah $2.64 \%$ yang berarti nilai EH untuk VOK $>1$ juga belum efisien. Sehingga penambahan VOK perlu dilakukan dalam hal ini seperti vaksin yang perlu ditingkatkan. Dimana biasanya dilakukan 2 bulan sekali menjadi 1 bulan sekali.

Nilai efisiensi tenaga kerja adalah $1.26 \%$ dan mendekati satu tetapi nilai efisiensi haruslah $=1$. Sehingga untuk nilai EH tenaga kerja $>1$ maka masih perlu ditambahkan jumlah tenaga kerja di UD. Puncak Jaya. Menurut suresty et al. (2008) jumlah pekerja untuk usaha ayam petelur yang ideal adalah 3 - 13 orang untuk 5000 ekor. Sedangkan UD. Puncak Jaya hanya 3 orang untuk 10.000 ekor.

Melalui perbandingan rasio NPM dengan HFP inilah maka dapat dilihat sejauhmana tingkat efisiensi harga untuk masing-masing variabel bebas yang dipakai dalam faktor produksi untuk mencapai optimalisasi produksi (Gany, et al. 2011).

\section{EFISIENSI EKONOMIS}

Nilai efisiensi ekonomis didapat dengan mengalikan nilai pada efisiensi teknis dan ekonomis ratarata. Hal ini karena suatu keadaan dikatakan efisien secara ekonomis apabila tercapai efisiensi teknis dan harga. Nilai efisiensi ekonomis adalah $5.80 \%$ sehingga masih jauh dari efisien. Oleh karena itu perlu sekali penambahan faktor-faktor produksi di UD. Puncak Jaya. Efisiensi ekonomis dapat diperoleh dari hasil kali antara efisiensi teknis dan efisiensi alokatif yang dalam hal ini, akan dilihat nilai rata-rata dari kedua efisiensi tersebut. Gany, et al (2014). Novita (2011) menuliskan bahwa efisiensi sering tidak tercapai ditingkat peternak hal ini dikarenakan keterbatasan pengetahuan dan modal yang dimiliki peternak.

\section{KESIMPULAN}

1. Mekanisme produk peternakan ayam petelur di UD. Puncak Jaya dilakukan dengan mempertimbangkan profit yang didapat seperti penggunaan bibit jenis Isa Brown, penggunaan pakan lengkap, vaksinasi dilakukan 2 bulan sekali, penggunaan obat dan suplemen yang rutin, serta tidak menambah jumlah tenaga kerja pada kandang $\mathrm{C}$ yang populasinya lebih besar.

2. Profit maksimal jangka pendek yang diperoleh adalah 33.53 juta per bulan. Variabel harga bibit, pakan, vaksin obat, dan tenaga kerja berpengaruh secara bersama - sama terhadap profitabilitas

3. Variabel biaya bibit, pakan, vaksin dan obat berpengaruh negative namun biaya tenaga kerja berpengaruh positif terhadap profitabilitas.

4. Tidak terdapat perbedaan profitabilitas diantara kandang $A B$ dan $C$ karena jumlah ternak sama.

5. Efisiensi teknis, harga dan ekonomis belum tercapai sehingga masih diperlukan penambahan faktor-faktor produksi. Nilai efisiensi teknis adalah 1.72, efisiensi harga adalah 3.37 dan efisiensi ekonomis adalah 5.83. Nilai efisiensi teknis mendekati satu berarti usaha mendekati efisien terbukti usaha berjalan sejak tahun 2005.

\section{DAFTAR PUSTAKA}

Achoja, 2014. Allocative Efficiency Of Feeds Among Poultry Farmers In Delta State, Nigeri. Russian Journal of Agricultural and Socio-Economic Sciences, 2(14). Department of Agricultural Economics and Extension,Delta State University, Nigeria.

Agustin, 2014. The elasticity of chickhen egg's price in west java. http://jurnal.unpad.ac.id/ejournal/article/view/6297/3199. 
Celli, M. 2013. Determinants of economies of scale in large businesses - A survey on UE listed firms. American Journal of Industrial and Business Management, 2013, 3, 255-261. http://dx.doi.org/10.4236/ajibm.2013.33031 (http://www.scirp.org/journal/ajibm).

FAO, 2013. Egg Production in Asia. http://www.fao.org/home/en/.

Gany. 2011. Efisiensi Faktor-Faktor Produksi Dan Kemitraan Guna Meningkatkan Produksi Usahatani Kedelai Di Distrik Makimi Kabupaten Nabire Propinsi Papua. Http://Pasca.Unhas.Ac.Id/Jurnal/Files/8d2ba9fd5bd384b1b631ade607867d6a.Pdf

Giyanto, 2010. Pengaruh Modal Usaha, Tenaga Kerja, Tingkat Pendidikan, Pengalaman Usaha, Jangkauan Pemasaran dan Krisis Ekonomi Terhadap Keberhasilan Batik Di Kampung Batik Kliwonan Kecamatan Masaran Kabupaten Sragen. Laporan Hasil Penelitian. UNS. Surakarta.

Hyline Management Guide. 2016. W 36 Commercial Layer. http://www.hyline.com/UserDocs/Pages/36_COM_ENG.pdf.

Hy-lineredbook. 2016. Vaksination. http://www.hyline.com/aspx/redb.

Juwandi, 2003. Analisis Keuntungan, Skala Usaha dan Efisiensi Ekonomi Relatif Usaha Ayam Petelur di Kabupaten Kendal. UNDIP. Semarang.

Mustika, 2011. Analisis Pendapatan Usaha Peternakan Ayam Petelur Di Kecamatan Takeran Kabupaten Magetan.

Https://Core.Ac.Uk/Download/Files/478/12346830.Pdf..

Novita. 2011. Analisis Efisiensi Produksi Dan Pendapatan Usaha Penggemukan Sapi PotongSerta Keberlanjutannya. Laporan Hasil Penelitian. IPB. Bogor

Poultrtryhub, 2016. Nutrient Requirement Of Egg Laying Chickhen . http://www.poultryhub.org/nutrition/nutrient-requirements/nutrient-requirements-of-egg-layingchickens/.

Rouf et al. 2014. Daya Saing Usaha Sapi Potong di Indonesia: Pendekatan Domestic Resources Cost. Balai Pengkajian Teknologi Pertanian Gorontalo.

Tamaluddin, 2014. Cara Menghitung Harga Telur Biar Untung. http://www.ternakpertama.com/2014/12/cara-menghitung-harga-telur-biar-untung.html

Tangendjaja. 2007. Inovasi Teknologi Pakan Menuju Kemandirian Usaha Ternak Unggas. http://peternakan.litbang.pertanian.go.id

Zumrotun, 2015. Jamu Sebagai Feed Additive Dan Feed Suplement Untuk Meningkatkan Efisiensi Dan Kesehatan Broiler. http://anwarhairul242. co.id/2015/01/jamu-sebagai-feed-additive-dan-feed.html. 